\title{
Measuring of noise emitted by moving vehicles
}

\author{
Tomáš Skrúcaný1, ${ }^{1}$, Branislav Šarkan ${ }^{1}$, Tomasz Figlus ${ }^{2}$, František Synák $^{1}$ and Ján Vrábel $^{1}$ \\ ${ }^{1}$ University of Žilina, Faculty of Operation and Economics of Transport and Communications, \\ Univerzitná 8215/1, 01026 Žilina, Slovakia \\ ${ }^{2}$ Silesian University of Technology, Faculty of Transport, Krasinskiego St. 8, 40-019 Katowice, \\ Poland
}

\begin{abstract}
The article aims to measure the intensity of the exterior noise of a vehicle in motion. It provides the results of the measurements of the external noise of selected vehicles in motion and the impact of selected factors on the sound level of driving. There are done two measurements in the paper. Results from the first one are comparing noise level of 9 passenger cars according to the Directive 71/157/EEC. The second one shows the road surface influence on the exterior noise of moving vehicle where the sound level was measured by a road whose surface was made of slightly degraded concrete, and at a different place of the same road, where the surface was renovated by applying asphalt mix onto it.
\end{abstract}

\section{Introduction}

The noise is defined as an unwanted sound which has an unpleasant and annoying effect. It is classified by the World Health Organisation as the second most serious environmental cause that threats the health of the population. The road transport is a major source of the environmental noise. The results of the European Environmental Agency's report show that one in four Europeans is exposed to the sound level above the upper limit laid down in European directives. The noise from the transport afflicts approximately 20 million of Europeans and approximately 8 million experience sleep disturbance. It is also responsible for nearly 43000 hospitalisations, 900000 cases of hypertension and 10000 cases of premature deaths per year $[1,2]$.

Based on the reasons referred to above, the issues have been implemented into the legislation. On the European level these comprise the Council Directive 70/157/EEC, the Directive 2002/49/EC of 25.06.2002 relating to the Assessment and Management of environmental noise, and the Regulation 540/2014 of the European Parliament and of the Council relating to the Sound level of motor vehicles. On the national level these comprise the Act No. 355/ 2007 Coll. on the Protection, Support and Development of the Public Health, Decree No. 549/2007 Coll. establishing details for the noise limits and the others.

The factors affecting the noise which is caused by the driving of a vehicle can be divided into two groups [2, 3].

The first group involves the noise from the vehicle engine and the noise arising from the driving due to air flowing around the vehicle and through its cooling and ventilating

\footnotetext{
*Corresponding author: tomas.skrucany@,fpedas.uniza.sk
} 
system. The important factors affecting the noise caused by the engine are the engine construction, rotations, technical condition, and tightness of the exhaust manifold.

The second group involves the noise arising from the motion of tyres at the road surface. The noise intensity is mainly influenced by the tyre construction, its size, type and pattern condition, building materials and technical conditions of the road surface, and speed of a vehicle $[4,5]$.

The aim of the article is to measure the exterior noise arising from the driving of selected vehicles and to assess the effect of the vehicle speed and building and technical conditions of the road surface on such a noise.

\section{Method of measurement}

\subsection{Exterior driving noise of chosen passenger cars}

The first part of the measurement was focused on the measuring the exterior noise of selected vehicles in motion. The list of selected vehicles with their performances is given in the Table 1.

Table 1. Used vehicles during the practical measurement.

\begin{tabular}{|c|c|c|c|c|c|c|}
\hline $\begin{array}{c}\text { Vehicle } \\
\text { brand }\end{array}$ & $\begin{array}{c}\text { Trade } \\
\text { name }\end{array}$ & $\begin{array}{c}\text { Engine } \\
\text { capacity } \\
{\left[\mathrm{cm}^{3}\right]}\end{array}$ & $\begin{array}{c}\text { Production } \\
\text { year }\end{array}$ & $\begin{array}{c}\text { Maximum engine } \\
\text { performance } \\
{[\mathrm{kW} / \mathrm{min}]}\end{array}$ & $\begin{array}{c}\text { Fuel } \\
\text { type }\end{array}$ & $\begin{array}{c}\text { Exterior noise of a } \\
\text { vehicle in motion } \\
\text { (methodology) } \\
{[\mathrm{dB}]}\end{array}$ \\
\hline Skoda & Octavia & 1896 & 2008 & $77 / 4000$ & Diesel & 69 \\
\hline VW & Passat & 1896 & 1996 & $81 / 4150$ & Diesel & 72 \\
\hline Renault & Thalia & 1149 & 2007 & $55 / 5500$ & Petrol & 70 \\
\hline Opel & Zafira & 1995 & 2004 & $74 / 4000$ & Diesel & 72 \\
\hline Opel & Vectra & 1598 & 1996 & $74 / 6200$ & Petrol & 73 \\
\hline Mazda & 323 & 1840 & 2000 & $84 / 6000$ & Petrol & 73 \\
\hline Peugeut & 206 & 1868 & 1998 & $51 / 4600$ & Diesel & 72 \\
\hline Skoda & Felicia & 1289 & 2001 & $50 / 5000$ & Petrol & 73 \\
\hline Renault & Clio & 1390 & 1997 & $55 / 5750$ & Petrol & 75 \\
\hline
\end{tabular}

The measurement was performed in accordance with Council Directive 71/157/EEC. According to this standard, A microphone must be placed at a distance of $7.5 \mathrm{~m}+/-0.2 \mathrm{~m}$ from a reference line of the roadway and $1.2 \mathrm{~m}+/-0.1 \mathrm{~m}$ above the ground. Its axis of maximum sensitivity must be horizontal and perpendicular to the vehicle roadway. When the vehicle front reaches the specific line, the accelerator fully opens as quickly as possible and is held in the fully opened position, until the rear vehicle intersects another specific line. Then, the accelerator closes as quickly as possible. The measurement conditions are depicted in the Fig. 1 [6]. 


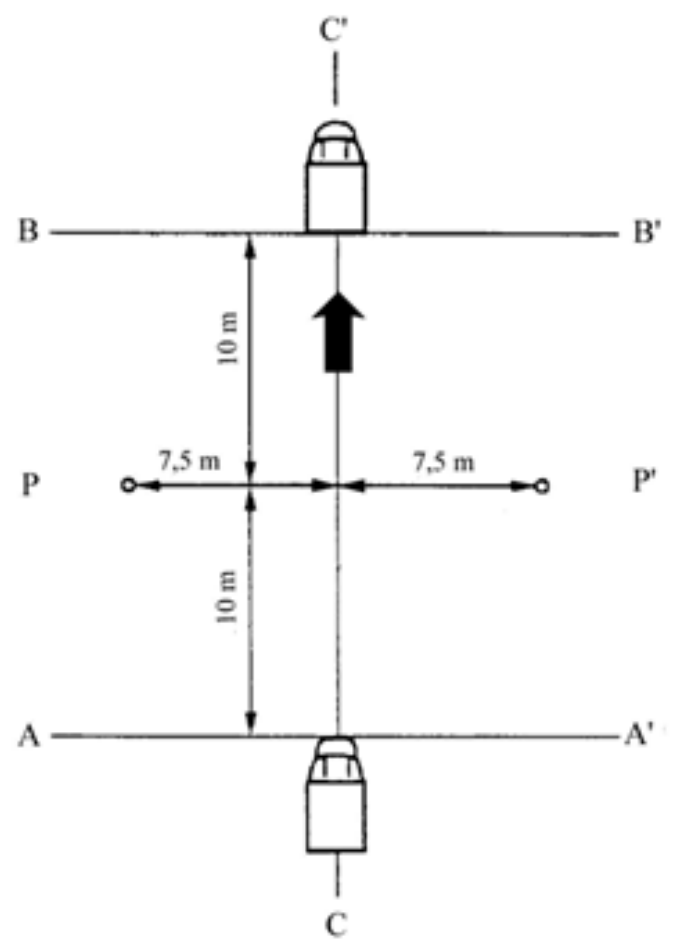

Fig. 1. The measurement of the noise of a vehicle in motion.

\subsection{Exterior driving noise influenced by road surface type}

The second part of the measurement was focused on the measuring of the impact of vehicle speed and road surface on the exterior vehicle noise. The measurements of traffic noise were performed using a Hyundai i40 Wagon car with a 1.7 litre engine. The measurement was performed at having constant engine speed of $2.200 \mathrm{rpm}$. The vehicle reaches the speed of $52 \mathrm{kmh}^{-1}$ at $3^{\text {rd }}$ gear, $75 \mathrm{kmh}^{-1}$ at $4^{\text {th }}$ gear and $98 \mathrm{kmh}^{-1}$ at $5^{\text {th }}$ gear.

The traffic noise tests were performed by road I/65 between the towns: Martin and Turčianske Teplice in Slovakia. The measurements were taken at two sections of the road. The surface of the first section was made of slightly degraded cement concrete, and the surface of the other section was previously renovated by applying a layer of asphalt mix onto the existing concrete layer [7 - 9].

The measurements were taken using the modified SPD method, in two directions of vehicle traffic, as shown in Fig. 2, at a controlled constant car speed. During the experiment, at least 3 runs of the vehicle, meaningful in terms of the measurement, were performed in each traffic direction. 


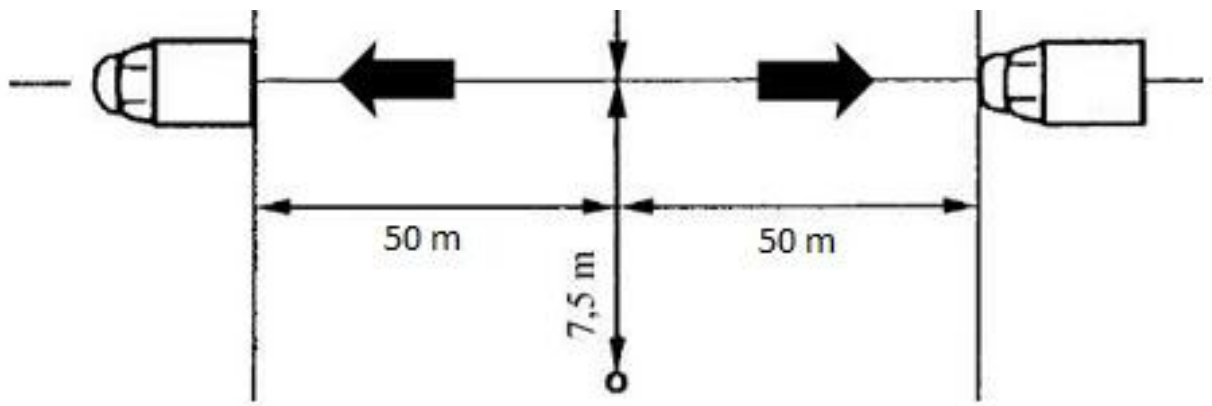

Fig. 2. Method of measurement.

\section{Measuring devices}

For both measurements it was used the Bruel\&Kjaer 2250 digital sound analyzer with antiwind attachments. Measurements were performed in the frequency range from $3 \mathrm{~Hz}$ to 20 $\mathrm{kHz}$, and in $1 / 3$ octave bands. The maximum sound level, $L_{A F m a x}$, and the equivalent sound level, $L_{\text {Aeq }}$, were recorded, and the results were adjusted by means of correction curve A $[10,11]$.

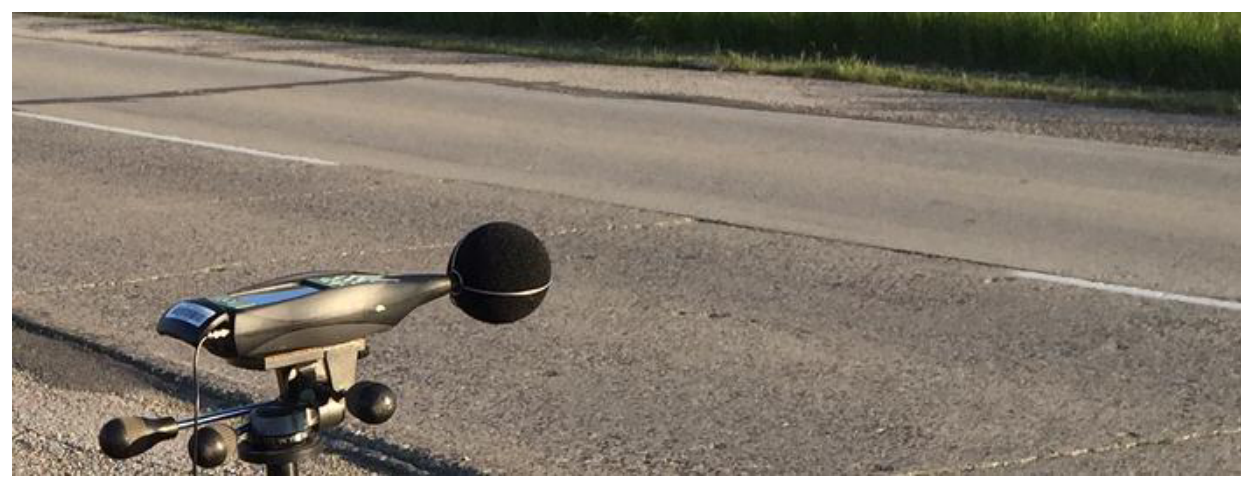

Fig. 3. View of the Bruel\&Kjaer 2250 sound analyzer during measurement. 


\section{Results and Discussion}

The Table 2 shows the exterior noise measured value of the selected vehicles in motion and these are compared with the "Methodology."

Table 2. Noise emission limits during the test of the vehicle in motion.

\begin{tabular}{|c|c|c|c|c|c|c|c|c|c|c|}
\hline \multirow{3}{*}{ Vehicle } & \multicolumn{6}{|c|}{ Exterior noise from moving vehicle } & \multirow{3}{*}{$\begin{array}{c}\text { Metho- } \\
\text { dology } \\
\text { dB }\end{array}$} & \multirow{3}{*}{$\begin{array}{l}\text { Highest } \\
\text { measured } \\
\text { value dB }\end{array}$} & \multirow{3}{*}{$\begin{array}{l}\text { Absolute } \\
\text { difference } \\
\text { dB }\end{array}$} & \multirow{3}{*}{$\begin{array}{c}\text { Relative } \\
\text { difference } \\
{[\%]}\end{array}$} \\
\hline & \multicolumn{2}{|c|}{$\begin{array}{c}1^{\text {st }} \\
\text { measurement }\end{array}$} & \multicolumn{2}{|c|}{$\begin{array}{c}2^{\text {nd }} \\
\text { measurement }\end{array}$} & \multicolumn{2}{|c|}{$\begin{array}{c}3^{\text {rd }} \\
\text { measurement }\end{array}$} & & & & \\
\hline & $\begin{array}{l}\text { Left } \\
\text { side } \\
\mathrm{dB}\end{array}$ & $\begin{array}{c}\text { Right } \\
\text { side } \\
\mathrm{dB}\end{array}$ & $\begin{array}{l}\text { Left } \\
\text { side } \\
\mathrm{dB}\end{array}$ & $\begin{array}{c}\text { Right } \\
\text { side } \\
\text { dB }\end{array}$ & $\begin{array}{c}\text { Left } \\
\text { side } \\
\text { dB }\end{array}$ & $\begin{array}{c}\text { Right } \\
\text { side } \\
\text { dB }\end{array}$ & & & & \\
\hline $\begin{array}{l}\text { Skoda } \\
\text { Octavia }\end{array}$ & 69 & 69.2 & 68 & 68.5 & 68.5 & 68.7 & 69 & 69.2 & +0.2 & $0 \%$ \\
\hline $\begin{array}{l}\text { Mazda } \\
323\end{array}$ & 70.1 & 69.9 & 70.7 & 70.5 & 71 & 69.9 & 73 & 71 & -2 & $-3 \%$ \\
\hline $\begin{array}{l}\text { Renault } \\
\text { Thalia }\end{array}$ & 70 & 69.8 & 70.5 & 70.3 & 71 & 71.2 & 70 & 71.2 & +1.2 & $2 \%$ \\
\hline $\begin{array}{l}\text { Skoda } \\
\text { Felicia }\end{array}$ & 71.9 & 71.9 & 71.8 & 71.7 & 72 & 71.9 & 73 & 72 & -1 & $-1 \%$ \\
\hline $\begin{array}{l}\text { Opel } \\
\text { Zafira }\end{array}$ & 72.3 & 72.4 & 72 & 72.1 & 71.8 & 72 & 72 & 72.4 & +0.4 & $1 \%$ \\
\hline $\begin{array}{l}\text { VW } \\
\text { Passat }\end{array}$ & 72.8 & 72.6 & 72.8 & 72.6 & 71.8 & 72 & 72 & 72.8 & +0.8 & $1 \%$ \\
\hline $\begin{array}{l}\text { Peugeot } \\
206\end{array}$ & 71.5 & 71.9 & 72.9 & 72.6 & 72.3 & 72.4 & 72 & 72.9 & +0.9 & $1 \%$ \\
\hline $\begin{array}{l}\text { Renault } \\
\text { Thalia (2) }\end{array}$ & 70.1 & 69.9 & 72.9 & 72.6 & 72,3 & 72.2 & 70 & 72.9 & +2.9 & $4 \%$ \\
\hline $\begin{array}{l}\text { Renault } \\
\text { Clio }\end{array}$ & 74.5 & 74.4 & 74.9 & 74.8 & 73.5 & 73.7 & 75 & 74.9 & -0.1 & $0 \%$ \\
\hline $\begin{array}{l}\text { Opel } \\
\text { Vectra }\end{array}$ & 77 & 77.1 & 76.9 & 76.8 & 76.9 & 77 & 73 & 77.1 & +4.1 & $6 \%$ \\
\hline
\end{tabular}

The lowest noise value was measured within the Škoda Octavia vehicle comprising 69.2 $\mathrm{dB}$. The highest value was reached by Opel Vectra vehicle with $77.1 \mathrm{~dB}$ where also the highest positive difference between the permitted and measured value was. The seven out of nine tested vehicles reached higher noise values than those defined in their Registration certificate in accordance with 540/2014 [12,13].

The results of the second part of the measurement are shown in the Fig. 4 and 5. The Figures present the results of measurements of the maximum sound level $L_{A F m a x}$, and of the equivalent sound level $L_{A e q}$, recorded in the entire frequency band at different car speeds [7]. 


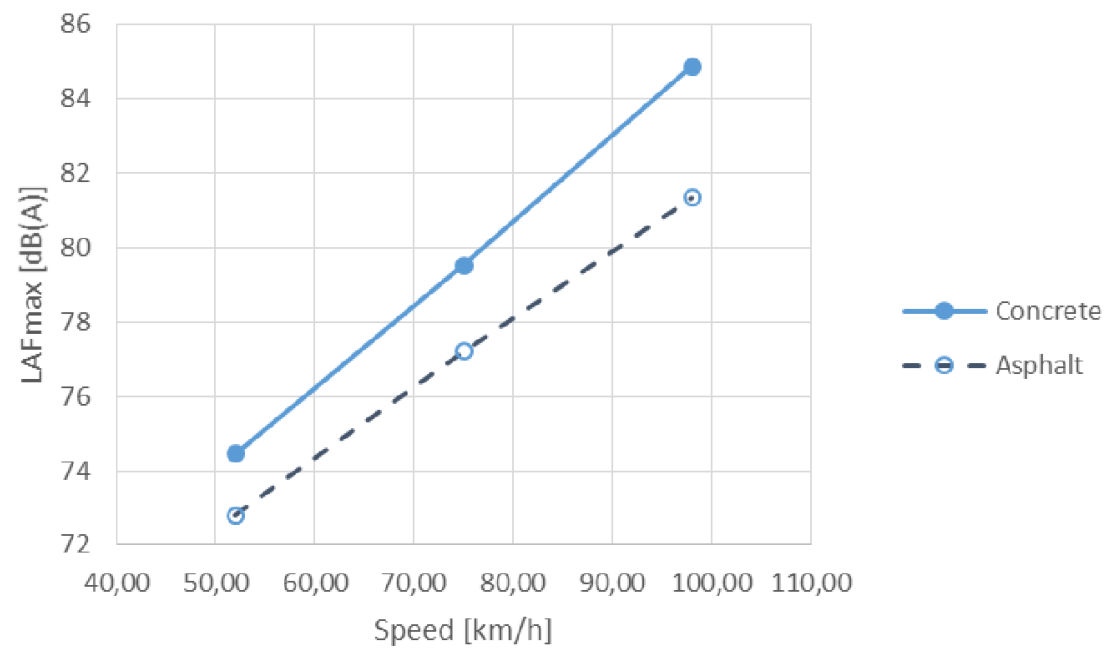

Fig. 4. The impact of driving speed and road surface on the LAFmax.

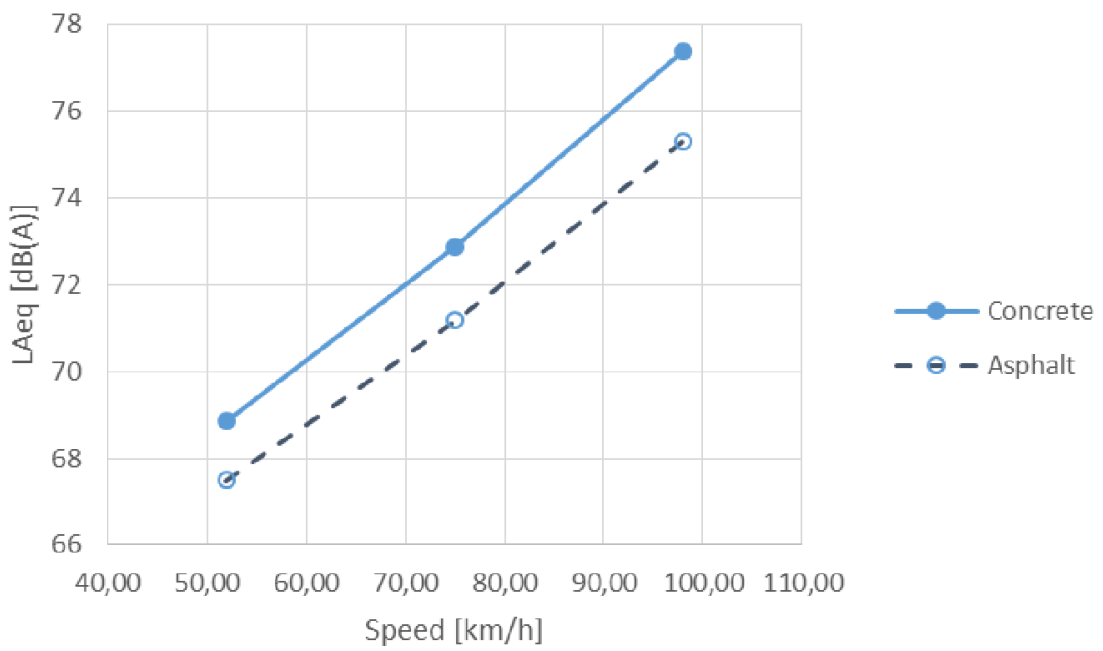

Fig. 5. The impact of driving speed and road surface on the $L_{\text {Aeq }}$.

The recorded values of the maximum sound level strongly depend on the car speed; on the cement concrete surface they reach values from $74.4 \mathrm{~dB}$ at a car speed of $52 \mathrm{kmh}^{-1}$, through $79.5 \mathrm{~dB}$ at $75 \mathrm{kmh}^{-1}$, up to $84.8 \mathrm{~dB}$ at $98 \mathrm{kmh}^{-1}$. It can be noticed that an increase in traffic speed by ca. $23 \mathrm{~km} / \mathrm{h}$ induces an increase in the maximum traffic noise level near the road by ca. $5 \mathrm{~dB}$. Comparing the recorded values of the maximum sound level for a car driving on a cement concrete surface with those recorded by the road with an asphalt mix surface, the differences amount to ca. 1.5-3 dB. Each time the sound levels recorded on the road with the asphalt mix surface are lower, and the differences in the values depend on the speed of the vehicle. Smaller differences are observed at lower traffic speeds [6]. 
While analyzing the existing traffic noise levels, it can be noticed that each time they exceeded the instantaneous values of $70 \mathrm{~dB}$, and at the highest traffic speed, $80 \mathrm{~dB}$. Such a sound level of sound is a nuisance to the environment. A change of the type of surface on the road under consideration and additionally, a reduction of the car speed may considerably contribute in this case to a reduction of the maximum sound level. For example, a change of the surface and a simultaneous car speed reduction from 98 to 75 $\mathrm{kmh}^{-1}$ may decrease the traffic noise by as much as $7.6 \mathrm{~dB}$.

For comparison purposes, an analysis was made of the equivalent sound level recorded during the running of the tested vehicle at a distance of ca. $50 \mathrm{~m}$ in front of and behind the measurement point. The sound level values in this case are lower than $70 \mathrm{~dB}$ only at a traffic speed of $52 \mathrm{kmh}^{-1}$. At higher traffic speeds, they exceed $70 \mathrm{~dB}$ each time, the maximum recorded value of $77.4 \mathrm{~dB}$ for the road with a cement concrete surface [6].

\section{Conclusion}

Noise emitted by moving vehicles is a problematic part of traffic emissions. Also measuring and evaluating the results is a complicated thing. It is still hard to evaluate the real noise influence on the human hearing and health despite the fact that there are directives, standards and regulations to solve the problematic of noise. Reached and described results in this paper reflect the real state of the noise level in traffic $[14,15,16]$. The results from the first part of measurements, passenger cars comparison, show that real noise level is almost higher than the value declared in the vehicle technical specification. It can be caused by different tires (depreciation, changed type, mark), technical condition of the engine, vehicle drive train or other technical parts $[17,18]$. The second result evaluation testifies the road surface influence on the noise level measured by one vehicle. The surface made from older and depreciated concrete panels is noisier than the renewed surface where the old surface was equipped by a new layer or asphalt. So not only the vehicle (type, technical condition, tires) but also the road surface is influencing the noise level of moving road vehicles.

\section{References}

1. J. Paslawski, Int. J. Environ. Pollut. 35, 275295 (2008)

2. T. Figlus, A. Wilk, Š. Liščák, Ł. Gozdek, Doprava a Spoje, 473-480, (2012)

3. W. Gardziejczyk, Transport Res. D-Tr E, 44, 93 - 104, (2016)

4. R. Rajamani, Vehicle dynamics and control (New York: Springer, 2012)

5. J. Y. Wong, Theory of ground vehicles (Ottawa, 2001)

6. T. Figlus, J. Gnap, T. Skrúcaný, P. Szafraniec, K. Żuradzki, CMDTUR (CMDTUR, Žilina, Slovakia, 2016)

7. B. Sarkan, O. Stopka, L. Chenguang, (to be published)

8. Z. Matuszak, M. Jaśkiewicz, K. Ludwinek, Z. Gawęcki, Selected Problems of Electrical Engineering and Electronics (WZEE'2015, Kielce, Poland, IEEE, New York, USA, 2015)

9. T. Figlus, J. Gnap, T. Skrucany, B. Sarkan, J. Stoklosa, Entropy, 18, 253 (2016)

10. P. Fiala, P. Drexler, D. Nespor, Z. SzabO, J. Mikulka, J. Polivka, Entropy, 18, 443 (2016)

11. J. Caban, P. Drozdziel, D. Barta, S. Liscak, Diagnostyka - Diagnostics, 15, 11 - 14 (2014) 
12. Regulation (EU) No. 540/2014, 16 April (2014)

13. Ordinance of The Transport Minister (Poland) No. 951, 22 August (2013)

14. S. Kubikova, A. Kalasova, L. Cernicky, $14^{\text {th }}$ Transport Systems Telematics Conference (TST, POLAND, 2014)

15. J. Gnap, V. Konecny, $9^{\text {th }}$ International Scientific Conference on Business Economics and Management (BEM, Izmir, TURKEY, 2015)

16. J. Ondrus, L. Cernicky, Communications : scientific letters of the University of Zilina. 18, 118 - 123 (2016)

17. V. Rievaj, L. Mokričková, Transport and communications, scientific journal, 1, 22 -26, (2016)

18. O. Stopka, I. Simkova, V. Konecny, Nase More, 62, 126 - 130 (2015) 